\title{
Managerial Shareholding, Asset Utilization Efficiency and Shareholders Wealth: A Structural
} Equation Model Analysis

Henry Kimathi Mukaria

Faculty of Business Studies, Chuka
University, Kenya.
Email:hkimathi@chuka.ac.ke
Licensed:
This work is licensed under a Creative
Commons Attribution 4.o License.

Keywords:

Managerial shareholdings

Asset utilization efficiency

Shareholders wealth

Structural equation modeling

Mediation effect.

JEL Classification

G10; J30.

Accepted: 22 June 2020

Published: 8 July 2020
Abstract

This paper examine whether managerial ownership impact upon shareholder wealth through efficacy or otherwise in the utilization of organizational resources. Specifically, it evaluates the causal mechanism of managerial shareholding on value via agency costs rather than just the direct effect. Herein, the study adopted structural equation modeling that enable estimate direct and indirect causal effect pathways for 64 firms listed at the Nairobi Securities Exchange as at 31st December 2017. The results show that managerial shareholding exerts negative influence on asset utilization and in turn a marginal positive effect is routed to shareholders wealth. The findings yield unequivocal substantiation that managerial shareholding is not only directly associated with shareholders wealth but also influences the investors wealth indirectly through efficacy in utilization of organizational resources.

Funding: This study received no specific financial support.

Competing Interests: The author declares that there are no conflicts of interests regarding the publication of this paper.

\section{Introduction}

The monitoring mechanisms in corporates continue to attract growing empirical research in contemporary corporate finance. Subsequently, vast literature document managerial ownership as a likely mechanism to control agency costs and its influence on firm performance (Chen, Guo, \& Mande, 2003; Demsetz \& Villalonga, 2001; Fabisik, Fahlenbrach, Stulz, \& Taillard, 2018; McConnell \& Servaes, 1990; McConnell, Servaes, \& Lins, 2008; Singh \& Davidson III, 2003). Agency mitigating mechanisms streamlines the interests between management and shareholders (Jensen \& Meckling, 1976). A mechanism of growing interest is prudence in the utilization of organizational resources that can construe minimal agency problems.

Managerial shareholding relates to equity ownership by the firm executives and board members (McConnell et al., 2008). Benson and Davidson III (2009) contend that insider equity holdings levels vary marginally over time yielding minor within firm variation. The arguments in literature suggest managerial owners act as a governance mechanism element that can either lead to greater or reduced agency problems. Agency costs emerge from costs to monitoring executives, agent's bonding expenditures or residual loss of welfare due to separate firm control and ownership (Jensen \& Meckling, 1976). The contemporary listed firms exhibit varied managerial shareholdings due to trading at the Securities Exchanges. Asset utilization denote the efficiency by firm managers to generate sales for investments in assets (Truong \& Heaney, 2013). Ang, Cole, and Lin (2000) opine that a high asset utilization ratio signify that assets produce substantial sales and point to lower agency conflicts. Moreover, small firms owned by managers do not experience agency costs. Rashid (2016) signal that managerial ownership shrinks agency cost via asset utilization ratio. Similarly, Singh and Davidson III (2003) argue that greater shareholding possession by managers enhance efficacy of resources application for large firms. Shareholders wealth is the ultimate goal for firms (Jensen \& Meckling, 1976). Inefficient use of assets manifest agency conflicts which reduces shareholders value (Truong \& Heaney, 2013). Thus, agency costs can act as a channel through which managerial shareholdings governance mechanisms diffuse asset productive efficiency on to investors' wealth.

In an attempt to expand managerial ownership governance mechanism insight, this study not only tests the influence of managers' shareholding on value but it also extends the empirical agency costs chain link to shareholders wealth. The context covers the Kenya listed firms at the Nairobi Securities Exchange (NSE) 
while adopting a structural equation modeling framework of ownership predicting efficacy in asset utilization and subsequently the connection of agency cost to shareholder value.

The rest of the article is structured as follows. The ensuing segment highlights literature review and hypotheses development. Thereafter, the data and variables measurement is outlined followed by the univariate and covariance analysis and then structural equation modeling fit output and discussion. The article ends by outlining conclusions and recommendations.

\section{Literature Review and Hypotheses Development \\ 2.1. Managerial Shareholding and Shareholders Wealth}

Jensen and Meckling (1976) posit in agency theory that equity concentration can align the incentives of firm executives, decline agency costs, and enhance shareholders wealth. Demsetz (1983) advanced a logical argument for existence of no link between ownership and performance while Fama and Jensen (1983) argued that a rise in insider share-ownership can be associated with managerial opportunism at the expense of external shareholdings. Successive works by McConnell and Servaes (1990) found a concave link between corporate insiders and value for US listed firms. Similarly, McConnell et al. (2008) while tracking variation in insider share holdings, report a curvilinear relation between insider ownership and firm value. However, Demsetz and Villalonga (2001) and Ahmed, Hossain, and Adams (2006) argue that ownership structure has no systematic impact on value provided managers strive towards maximizing shareholders' value. As well, the study arguments by Demsetz (1983) supports that ownership suffers from potential endogeneity.

A case of interest alignment between managers and owners reflects in analysis by Li, Moshirian, Nguyen, and Tan (2007) that indicate managerial shareholding has a positive effect on return on assets for Chinese State-owned enterprises. On the contrary, a two-stage least squares analysis by Zondi and Sibanda (2015) found that managerial ownership does not impact South Africa listed retail sector Tobin's Q in any direction. The analysis considered a limited sample of only 22 firms. Moreover, Berke-berga, Dovladbekova, and Abula (2017) found no significant relation between managerial ownership and Tobin's $Q$ but report a positive effect on return on assets for Baltic States listed firms. The studies do not return similar results even where the same performance measure proxy was adopted, notwithstanding the different countries contexts.

While controlling for fixed effects of Japanese firms context, Chen et al. (2003) concluded that Tobin's $q$ rise monotonically with managerial shareholding. Besides, Benson and Davidson III (2009) model a fixed effect model and two-stage least squares regression and establish an inverted U-shaped association between managerial ownership and Tobin's Q, a sign of interest alignment at low ownership levels and risk aversion for higher ownership proportions. In contrast, Fahlenbrach and Stulz (2009) found no adverse value effect for instances of large decreases in insider ownership from 1988 to 2003 for American firms. However, the analysis established that big increases in managerial ownership strengthen Tobin's $q$.

A recent analysis by Saifullahi, Mohammed, and Hassan (2015) highlight results revealing that managerial and independent directors' ownership exhibit significant but negative influence on the performance of listed conglomerate firms in Nigeria. Correspondingly, Fabisik et al. (2018) based on extensive data for more than 1800 large firms from 1988 to 2015, present evidence of negative relations between managerial ownership and Tobin's q. As well, the results show that firms with increased managerial equity holdings are worth less contrary to theoretical arguments.

Different statistical methods are employed by the aforementioned studies in a variety of contexts. However, studies in Kenya context were unavailable. Moreover, adopting a structural equation modeling framework of simultaneous equation of ownership enable addressed the issue of potential endogenity bias highlighted in empirical review. To this end, the delight in this article involved applying structural equation modeling on current dataset in Kenya context to estimate simultaneously the relationship between managerial shareholdings and investors wealth. While, established on the arguments above, null hypothesis 1 is constructed: The relationship between managerial shareholding and shareholders holders' wealth is not significant.

\subsection{Managerial Shareholding, Asset Utilization Efficiency and Shareholders Wealth}

Firm executives who own equities in firms which they manage can either utilize the organization resources for self-interests or for the benefit of all owners as postulated in the agency theory (Jensen \& Meckling, 1976). However, asset utilization evaluation systems can enhance monitoring and mitigate suboptimal investment by manager owners. Moreover, corporate boards can act as stewards who efficiently utilize organizational resources for the benefit of all shareholders, as premised by stewardship theory (Donaldson \& Davis, 1991). Herein, once interest is aligned, manager shareholders can influence wealth of shareholders via an intermediary mechanism depicting the efficacy in the utilization of organizations resources.

Vast empirical studies focus on examining the interrelation between managerial shareholdings and performance and; managerial shareholdings and asset utilization with no chain link to performance. For instance, while controlling for endogeneity, Rashid (2016) estimated the bond subsisting between management shareholding and asset utilization using instrumental regression for 110 listed firms in Bangladesh. The study output confirm that managerial holdings mitigate agency costs as proxied by asset utilization. In other case, 
Truong and Heaney (2013) model asset utilization as a function of insider shareholding and found a link between insider shareholding and agency costs. Furthermore, Aydın and Kulali (2018) provide evidence in support of efficiency in asset utilization increasing with the executives' ownership share for firms in Eastern Europe, a sign of mitigation of agency costs. In contrast, Florackis (2009) cross section analysis based on 440 UK firms demonstrate an inverse link between managerial ownership and asset turnover at low levels of directors ownership but positive link for higher ownership levels. However, the studies do not extend the empirical chain link effect on to shareholders value.

Earlier empirical studies by Ang et al. (2000) contend that the levels of agency cost are inversely associated to the manager's share interest in small non-listed US businesses. Yet again, Singh and Davidson III (2003) examine the role of ownership elements in alleviating agency problems for large US firms. Both studies findings point to reduction in agency problems on aligning insider and external shareholders interest but do not extend an empirical prediction of agency conflict on to shareholders wealth.

The empirical studies either disclose a causality between managerial shareholdings and asset utilization or managerial ownership and shareholders wealth. The studies capturing the flow of agency cost on the link between ownership and value are missing with no attention accorded to such chain links. Moreover, no existing studies were available employing structured equation modelling to examine the inter-relationships among the corporate mechanisms variables. Additional insights can be revealed by exploring the monitoring systems intermediary role. Thus in an effort to enlighten on the causality between directors ownership and value, this paper examine that relationship in conjunction with the pathways through which directors' shareholding emit their influence in the utilization of organizational resources that in turn enhance value. Accordingly the null hypothesis 2 constructed: The intermediary role of asset utilization efficiency on the relationship between managerial shareholding and equity holders' wealth is not significant.

\subsection{Data, Variables Definition and Methodology}

The data on management shareholding and asset utilization (total assets and sales) were retrieved from the periodic annual reports circulated annually by the listed companies. The data to construct the shareholders wealth based on market value was aggregated from Nairobi Securities Exchange daily share prices investor reports circulations. The sample of study spans the period from 2010 to 2017 of 64 firms. The firms with missing data and others with missing company-year observations were excluded.

The definitions of variable are presented in Table 1.

Table-1. Variables and operationalization.

\begin{tabular}{l|c|l}
\hline Variable & Abbreviation & Proxy \\
\hline Managerial Shareholding & MS & Ratio of board members shares ownership \\
\hline Asset Utilization Efficiency & AUE & Annual sales to total assets ratio \\
\hline Shareholders Wealth & SW & Market to book value of equity \\
\hline
\end{tabular}

The methodology was premised on Baron and Kenny (1986) mediation framework where an independent variable predict another variable (mediator) that eventually predict the outcome variable. Structural equation modeling (SME) was adopted to scrutinize the series of dependent relationships simultaneously. In particular, the path analysis consisting of a series of regressions, was considered in partial mediation causal mechanism (MacKinnon, Fritz, Williams, \& Lockwood, 2007). In this case, the path was specified as managerial shareholding diffusing agency costs that in return influence shareholders wealth. Moreover, the direct link between managerial ownership and shareholders value was also estimated. Specially, structural equation modeling enabled to fit a single model to estimate the direct, indirect (mediation) and total effects among managerial shareholding, agency costs and shareholders wealth. The product of path coefficients ( $\left.\mathrm{a}^{*} \mathrm{~b}\right)$ capture the indirect effect (Kline, 2005). Figure 1 present the model pathway.

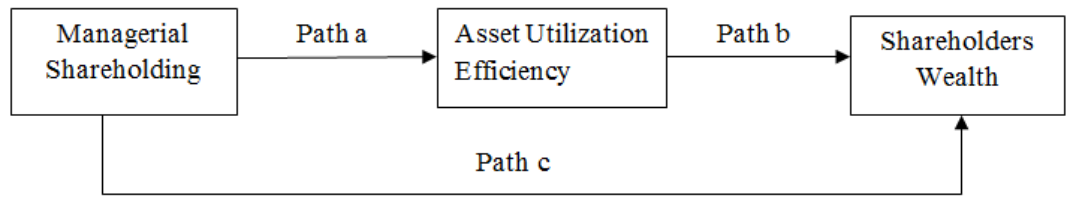

Figure-1. The Path component of the direct and indirect effects. Source: Baron and Kenny (1986).

The path model summarizes the hypothesized associations where managerial shareholding predict asset utilization efficiency which in turn predict the shareholders wealth.

\subsection{Descriptive Statistics of Variables}

This section highlights the summary descriptive statistics for all variables in Table 2. 
Table-2. Descriptive statistics.

\begin{tabular}{l|l|l|l|l|l}
\hline Variable & Mean & Std. Dev & Median & Min & Max \\
\hline Managerial Shareholdings & 0.12 & 0.20 & 0.01 & 0.00 & 0.71 \\
\hline Asset Utilization Efficiency & 0.72 & 0.81 & 0.47 & 0.08 & 4.52 \\
\hline Shareholders Wealth & 1.63 & 1.22 & 1.37 & 0.2 & 5.64 \\
\hline
\end{tabular}

The descriptive statistics summary in Table 2 show that shareholders wealth reveal a mean value of 1.63 with a deviation of 1.22. The minimum and maximum value representing the shareholders wealth was 0.01 and 5.64 in that order. The mean managerial shareholdings was 0.12 with a minimum of zero and a maximum of 0.71 ownership proportion. The mean shareholdings of the board members observation represent a fairly low ownership share across the firms. Meanwhile, the mean asset utilization of 0.72 signifies that each shilling invested in organizational resources generate 72 cents of revenue. The minimum value of 0.08 infer that some firm managers may have deployed assets in unproductive investments that do not generate adequate cash flows. This can be a pointer to inherent higher agency costs in some listed firms. On the other hand, the maximum asset turnover of 4.52 implies that some firm managers efficiently utilize the firm assets. In essence, the improved efficacy in utilization of assets can signify decreased agency problems.

\subsection{Covariance Analysis}

A bivariate covariance summary of the variables is represented in Table 3.

\begin{tabular}{|c|c|c|c|}
\hline Variable & $\begin{array}{c}\text { Managerial } \\
\text { Shareholdings }\end{array}$ & $\begin{array}{c}\text { Asset } \\
\text { Utilization }\end{array}$ & $\begin{array}{c}\text { Shareholders } \\
\text { Wealth }\end{array}$ \\
\hline Managerial Shareholdings & 1.000 & & \\
\hline \multirow[t]{2}{*}{ Asset Utilization Efficiency } & $-.178^{*}$ & 1.000 & \\
\hline & 0.0297 & & \\
\hline \multirow[t]{2}{*}{ Shareholders Wealth } & $-.282 *$ & .117 & 1.000 \\
\hline & .039 & .051 & \\
\hline
\end{tabular}

The covariance matrix in Table 3 show a statistically significant negative correlation of 0.178 between managerial shareholdings and asset utilization ratio. Likewise, a negative correlation of equity ownership by directors on the shareholders wealth of -0.282 was observed. Meanwhile, asset utilization ratio manifest positive but not statistically significant association with shareholders wealth.

\section{SEM Results and Discussions}

SEM model test of the research hypotheses examine whether each of the structural path effect was statistically significant via Lavaan (Rosseel, 2012). The ensuing saturated mediation model with zero degrees of freedom returned a goodness-of-fit index (GFI) of 1. Therefore, in order to achieve robust results, the Sobel test and subsequently the bootstrap confidence intervals were applied to test the significance of the indirect (mediation) effect (Kline, 2005). The results of the fit measures are summarized in Table 4.

Table-4. Model fit measures results

\begin{tabular}{|c|c|c|c|c|}
\hline Regressions: & Estimate & Std. Err & z-value & $\mathbf{P}(>|\mathbf{z}|)$ \\
\hline \multicolumn{5}{|l|}{ Shareholders Wealth } \\
\hline Asset Utilization Efficiency (b) & 0.098 & 0.199 & 4.492 & 0.004 \\
\hline Managerial Shareholdings (c) & -1.668 & 0.820 & -2.035 & 0.022 \\
\hline Managerial Shareholdings (a) & -0.741 & 0.551 & -2.345 & 0.017 \\
\hline \multicolumn{5}{|l|}{ Asset Utilization Efficiency } \\
\hline \multicolumn{5}{|l|}{ Intercepts: } \\
\hline & Estimate & Std. Err & z-value & $\mathrm{P}(>|\mathrm{z}|)$ \\
\hline Shareholders Wealth & 1.768 & 0.248 & 7.132 & 0.000 \\
\hline Asset Utilization Efficiency & 0.816 & 0.128 & 6.382 & 0.000 \\
\hline \multicolumn{5}{|l|}{ Variances: } \\
\hline & Estimate & Std. Err & z-value & $\mathrm{P}(>|\mathrm{z}|)$ \\
\hline Shareholders Wealth & 1.348 & 0.259 & 5.196 & 0.000 \\
\hline Asset Utilization Efficiency & 0.629 & 0.121 & 5.196 & 0.000 \\
\hline
\end{tabular}


Table 6 results highlights that the direct effect of managerial shareholding $(\beta=-1.668, p=0.022)$ is significant but inversely related to shareholders wealth. The indirect effect of managerial shareholding that diffuse through agency cost is $(\beta=-0.741, \mathrm{p}=0.017)$ and is also statistically significant. Moreover, a further statistically significant but negative lesser effect $(\beta=-0.098, p=0.004)$ was eventually channeled to shareholders wealth. Overall, the managerial equity holding is associated with shareholders wealth indirectly through organizational resources utilization efficiency. MacKinnon et al. (2007) contend that the path coefficient product $\left(\mathrm{a}^{*} \mathrm{~b}\right)$ in SEM framework is ideal for mediation test. Thus, in order to subject the fit measure to rigor, the Sobel test based on delta method was applied on the product of path coefficient denoting the indirect effect (Sobel, 1982). The results are summarized in Table 5.

Table-5. Sobel test indirect effect results.

\begin{tabular}{l|c|c|c|c}
\hline Defined Parameters: & Estimate & Std. Err & z-value & $\mathbf{P}(>|\mathbf{z}|)$ \\
\hline Direct Effect & -1.668 & 0.820 & -2.035 & 0.022 \\
\hline Indirect Effect & -0.073 & 0.157 & -4.462 & 0.021 \\
\hline Total Effect & -1.740 & 0.808 & -2.154 & 0.031 \\
\hline
\end{tabular}

The Sobel test of significance reveal that the indirect effect of managerial shareholdings on shareholders wealth via asset utilization ratio $(\beta=-0.073, p=0.035)$ is statistically significance. Sobel test assumes that sampling distribution of the indirect effect is normally distributed (Kline, 2005). In that case, the product of coefficients along the indirect path effect were further subjected to bootstrapping using the percentile method so as to achieve robust checks (Bollen \& Stine, 1990). Table 6 summarize the significance test results of bootstrapping procedure of 1000 samples.

Table-6. Significance test results of the bootstrapping percentile method.

\begin{tabular}{l|c|c|c|c|c|c|c}
\multicolumn{1}{c}{ Table-6. Significance test results of the bootstrapping percentile method. } \\
\hline Variable pair & Label & Estimate & Se & Z & pvalue & ci.lower & ci.upper \\
\hline SW $\sim$ AUE & b & 0.098 & 0.190 & -0.517 & 0.035 & -0.221 & -0.678 \\
\hline SW $\sim$ MS & c & -1.668 & 0.523 & -3.191 & 0.001 & -2.906 & -0.712 \\
\hline AUE $\sim$ MS & a & -0.741 & 0.402 & -1.843 & 0.044 & -1.574 & -0.027 \\
\hline direct $:=\mathrm{c}$ & direct & -1.668 & 0.525 & -3.175 & 0.001 & -2.906 & -0.712 \\
\hline indirect $:=$ a*b & indirect & -0.073 & 0.114 & -4.638 & 0.024 & -0.318 & -0.489 \\
\hline total $:=\mathrm{c}+\left(\mathrm{a}^{*} \mathrm{~b}\right)$ & total & -1.740 & 0.54 & -3.22 & 0.001 & -2.876 & -0.703 \\
\hline
\end{tabular}

As revealed by bootstrap confidence intervals test of significance results in Table 6 managerial shareholding significantly predicts $(\beta=0.741, p=0.024)$ asset utilization ratio ( $p$ ath a) and in turn asset utilization ratio significantly predicts $(\beta=0.098, \mathrm{p}=0.035)$ shareholders wealth (path $\mathrm{b})$. Thus null hypothesis 1 and 2 are rejected. It thus follows that managerial shareholding has a significant inverse effect on shareholders wealth and affect shareholders wealth indirectly through asset utilization. Figure 2 illustrates the estimates for the partial mediation model pathway.

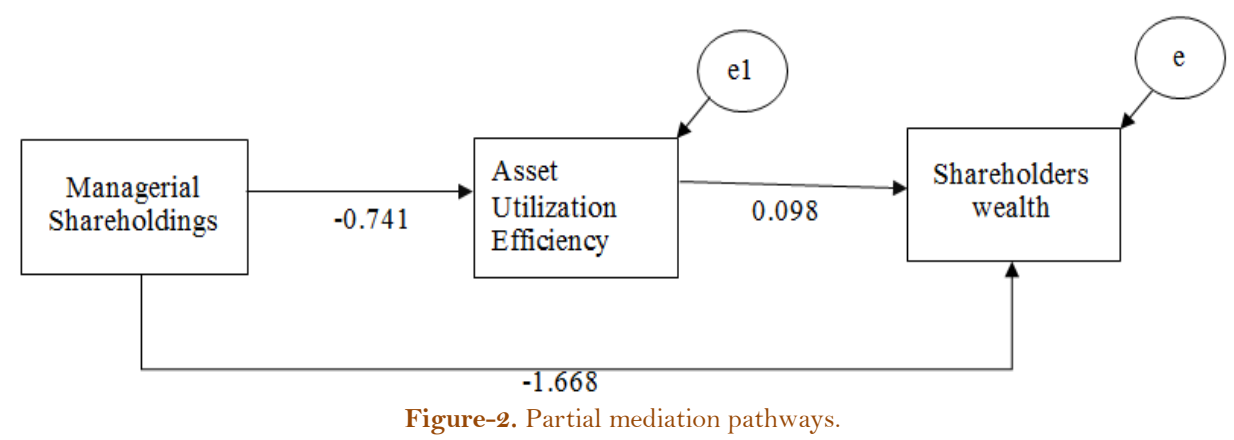

Figure 2 shows that path (c) coefficient -1.668 representing channeling of negative influence mechanisms directly to shareholders wealth while path (a) and (b) coefficients - 0.741 and 0.098 respectively are estimates for the indirect pathway influencing shareholders wealth. All the path coefficients are reliably different from zero. Besides, the figure reveal that the share of the total effect which is mediated is a mere 0.04 while the direct effect to total effect account for 0.96. The proportion of the mediated (indirect) effect of the direct effect of stood at 0.44. Indeed, managerial shareholdings has a greater direct influence predicting shareholders wealth. Moreover, the path coefficients from managerial shareholding via asset utilization efficacy to shareholders wealth were both significant. The managerial shareholding exert negative influence via asset utilization but a marginal positive productivity is in turn routed to maximizing shareholders wealth. The scanty productive efficiency emitted on utilization of organizational resources does not over turn the negative effect originating from managerial shareholders. In general, a partial mediation is evident whereby the 
influence of managerial shareholders is partially interceded by proficiency in organizational resource utilization, but there exist a direct effect between managerial shareholders and shareholders wealth.

The direct path capture managerial shareholding influence that erode investors wealth. The finding is robust since the study adopts SEM that remedies latent endogeneity of ownership structure cited in previous literature. The findings support Saifullahi et al. (2015) and Fabisik et al. (2018) studies that present negative relation between manager owners and shareholders wealth. The findings are in contrast to theoretical arguments supporting shareholding by the executives to mitigate agency problems. Moreover, the findings conflicts results by Demsetz and Villalonga (2001) and Zondi and Sibanda (2015); Fahlenbrach. and Stulz (2008) that managerial ownership has no impact on value. Similarly, the findings do not support Li et al. (2007) claim of a positive link between managerial ownership and value.

The indirect effect capture managerial shareholding impact on shareholders wealth through inefficient utilization of firm resources. The negative effect between managerial shareholdings on investors' wealth passes via ineptitude in asset deployment that suggest managerial shareholding prompt facets of agency costs. The inside ownership potentially misaligns the interests of owners and managers. The findings are consistent with Florackis (2009) of an inverse association between managerial ownership and asset turnover. Equally, Ang et al. (2000) reported that asset-turnover ratio varies inversely with shareholding. Nevertheless, the findings are inconsistent with Rashid (2016); Truong and Heaney (2013) and Singh and Davidson III (2003) findings that managerial holdings mitigate agency manifested in asset utilization. Moreover, the results are not in support of the practical application and relevance of the stewardship theory proposition on prudence in the safeguard of organizational resources.

\section{Conclusions and Recommendations}

This paper provide significant contribution on relationship among managerial shareholding, asset utilization and shareholders wealth. Overall, the study investigate not only the direct effect of managerial shareholding on investors wealth but also the chain link of managerial shareholding effect diffusion via the utilization of organizational resources to impact the shareholders wealth. Besides, the study is valuable as it adopts a structural equation modeling framework to enable resolve the issue of potential endogenity bias highlighted in past ownership empirical reviews thus offering superior causal-effect links among managerial shareholding asset utilization and shareholders wealth. The estimates of the structural equation model yield unequivocal evidence that managerial shareholding not only directly predict shareholders wealth but also indirectly predict through the deployment of organizational resources. As well, the results extend significance of efficacy in the application of assets that when incorporated in the SME model, its influence enrich the total effect of managerial shareholding on shareholders wealth. Indeed, an efficacy evaluation system in asset deployment may foster interests alignment. Thus, the wasteful influence of management shareholding on investors' wealth can be limited by monitoring investments efficiency to maximize shareholders wealth.

The inferences of the study enlighten that managerial shareholding does not emit ideal benefits to investors inform of reduced agency costs. Undeniably, this raises reservations on the practice effectiveness of encouraging equity ownership by executives and board members and call for review of such policies. Additionally, managerial shareholders influence in decision making indicate sub-optimal asset utilization and thus require sound governance mechanisms checks. However, the eroding effect (agency conflicts) on shareholders wealth appear to be lessened on instituting monitoring mechanisms in the utilization of resources, although the positive influence channeled through deployment of firm resources is marginal. To this end, the study also recommends that organizations to continually monitor assets efficacy so as to alleviate agency conflicts of sub-optimal asset application in the generation of revenues and maximize shareholder wealth. Further areas of study can focus of alternative ownership structures and monitoring mechanisms to extend research findings in corporate governance. This study is limited to publicly traded firms in Kenya.

\section{References}

Ahmed, K., Hossain, M., \& Adams, M. B. (2006). The effects of board composition and board size on the informativeness of annual accounting earnings. Corporate Governance: An International Review, 14(5), 418-431.Available at: https://doi.org/10.1111/j.1467-8683.2006.00515.x.

Ang, J. S., Cole, R. A., \& Lin, J. W. (2000). Agency costs and ownership structure. The Journal of Finance, 55(1), 81-106.

Aydın, N., \& Kulali, G. (2018). Asset utilization efficiency and ownership structure: Evidence from emerging and developing Eastern Europe. Journal of Eastern European and Central Asian Research, 5(1), 18-18.Available at: https://doi.org/10.15549/jeecar.v5i1.186.

Baron, R. M., \& Kenny, D. A. (1986). The moderator-mediator variable distinction in social psychological research: Conceptual, strategic and statistical considerations. Journal of Personality and Social Psychology, 51(6), 11731182.Available at: https://doi.org/10.1037/0022-3514.51.6.1173.

Benson, B. W., \& Davidson III, W. N. (2009). Reexamining the managerial ownership effect on firm value. Journal of Corporate Finance, 15(5), 573-586.Available at: https://doi.org/10.1016/j.jcorpfin.2009.08.002.

Berke-berga, A., Dovladbekova, I., \& Abula, M. (2017). Managerial ownership and firm performance: Evidence of listed companies in the bltics. Polish Journal of Management Studies, 15(2), 273- 283.Available at: https://doi.org/10.17512/pjms.2017.15.2.25. 
Bollen, K. A., \& Stine, R. (1990). Direct and indirect effects: Classical and bootstrap estimates of variability. Sociological Methodology, 20, 115-140.Available at: https://doi.org/10.2307/271084.

Chen, C. R., Guo, W., \& Mande, V. (2003). Managerial ownership and firm valuation: Evidence from Japanese firms. Pacific-Basin Finance Journal, 11 (3), 267-283.

Demsetz, H. (1983). The structure of ownership and the theory of the firm. The Journal of Law and Economics, 26(2), 375390.

Demsetz, H., \& Villalonga, B. (2001). Ownership structure and corporate performance. Journal of Corporate Finance, 7(3), 209-233.

Donaldson, L., \& Davis, J. H. (1991). Stewardship theory or agency theory: CEO governance and shareholder returns. Australian Journal of Management, 16(1), 49-64.Available at: https://doi.org/10.1177/031289629101600103.

Fabisik, K., Fahlenbrach, R., Stulz, R. M., \& Taillard, J. P. (2018). Why are firms with more managerial ownership worth less? National Bureau of Economic Research, Working Paper No. w25352.

Fahlenbrach, R., \& Stulz, R. M. (2009). Managerial ownership dynamics and firm value. Journal of Financial Economics, 92(3), 342-361.Available at: https://doi.org/10.1016/j.jfineco.2008.06.005.

Fahlenbrach., R., \& Stulz, R. M. (2008). Managerial ownership dynamics and firm value. Journal of Financial Economics, 92(3), 342-361.

Fama, E. F., \& Jensen, M. C. (1983). Separation of ownership and control. The Journal of Law and Economics, 26(2), 301325.

Florackis, C. (2009). Agency costs and corporate governance mechanisms: Evidence for UK firms. International Journal of Managerial Finance, 4(1), 37-59.

Jensen, M. C., \& Meckling, W. H. (1976). Theory of firm: Managerial behaviour, agency costs and ownership structure. Journal of Financial Economics, 3, 305-360.Available at: https://doi.org/10.1007/978-94-009-9257-3_8.

Kline, R. B. (2005). Principles and practice of structural equation modeling (2nd ed.). New York: The Guilford Press.

Li, D., Moshirian, F., Nguyen, P., \& Tan, L.-W. (2007). Managerial ownership and firm performance: Evidence from China's privatizations. Research in International Business and Finance, 21(3), 396-413.Available at: https://doi.org/10.1016/j.ribaf.2007.02.001.

MacKinnon, D. P., Fritz, M. S., Williams, J., \& Lockwood, C. M. (2007). Distribution of the product confidence limits for the indirect effect: Program PRODCLIN. Behavior Research Methods, 39(3), 384-389.Available at: https://doi.org/10.3758/bfo3193007.

McConnell, J. J., \& Servaes, H. (1990). Additional evidence on equity ownership and corporate value. Journal of Financial Economics, 27(2), 595-612.Available at: https://doi.org/10.1016/0304-405x(90)90069-c.

McConnell, J. J., Servaes, H., \& Lins, K. V. (2008). Changes in insider ownership and changes in the market value of the firm. Journal of Corporate Finance, 14(2), 92-106.Available at: https://doi.org/10.1016/j.jcorpfin.2008.02.001.

Rashid, A. (2016). Managerial ownership and agency cost: Evidence from Bangladesh. Journal of Business Ethics, 137(3), 609-62 1.Available at: https://doi.org/10.1007/s10551-015-2570-z.

Rosseel, Y. (2012). Lavaan: An R package for structural equation modeling and more. Version 0.5-12 (BETA). Journal of Statistical Software, 48(2), 1-36.

Saifullahi, M. A., Mohammed, A., \& Hassan, S. U. (2015). Ownership diversity and corporate performance: Evidence from Nigerian conglomerates firms. Journal of Basic and Applied Research, 1(1), 89-101.

Singh, M., \& Davidson III, W. N. (2003). Agency costs, ownership structure and corporate governance mechanisms. Journal of Banking \& Finance, 27(5), 793-816.Available at: https://doi.org/10.1016/s0378-4266(01)00260-6.

Sobel, M. E. (1982). Asymptotic confidence intervals for indirect effects in structural equation models. Sociological Methodology, 13, 290-312.Available at: https://doi.org/10.2307/270723.

Truong, T. T., \& Heaney, R. (2013). The determinants of equity agency conflicts between managers and shareholders: Evidence from Australia. Journal of Multinational Financial Management, 23(4), 314-326.Available at: https://doi.org/10.1016/j.mulfin.2013.05.001.

Zondi, S., \& Sibanda, M. (2015). Managerial ownership and firm performance on selected JSE listed firms. Corporate Ownership \& Control, 12(3), 233-241.Available at: https://doi.org/10.22495/cocv 12i3c2p3. 